\title{
SUSILO BAMBANG YUDHOYONO'S SPEECH THE ROLE OF THE MILITARY IN CHANGING THE WORLD: SEMANTIC ANALYSIS
}

\author{
Nurlaila Sari Harahap1; Umar Mono2; Bahagia Tarigan³ \\ Universitas Sumatera Utara1,2,3 \\ Corresponding email: ilaharahap719@gmail.com
}

\begin{abstract}
This research entitled Susilo Bambang Yudhoyono's Speech The Role Of The Military In Changing The World: Semantic Analysis. The objectives of this research are to find out the types of associative meaning, describe the realization of associative meaning in Susilo Bambang Yudhoyono's speech, and the reason of using associative meaning in the data. The data of this research were utterances. The source of data was Susilo Bambang Yudhoyono's role of the military in changing world speech. The method used in this research was descriptive qualitative adopted data analysis procedures proposed by Miles \& Huberman. This study focused on associative meaning by using Leech's theory. The result showed that there were the different amount of the types of associative meaning used in SBY's speech. The affective meaning dominated the frequent type of associative meaning in SBY's speech with 58 utterances (44.3\%) from all total 131 utterances. This type was not much disparity within the number of connotative meaning used that only (3.1\%) lower than affective meaning, about 54 utterances or in amount (41.2\%) rather than another two types which seemed to have a low priority to use. The use of social meaning was only discovered in amount 12 utterances or $(9.2 \%)$. Then, the least of all types of meaning used in SBY's speech was reflected and collocative meaning. The number of reflected and collocative meaning only reached $(3.1 \%)$ and $(2.3 \%)$ or it was only $3-4$ utterances found from the whole of speech utterances. SBY tends to use connotative and affective meaning yet he still used social, reflected and collocative meaning with the low rate.
\end{abstract}

Keywords: semantics, associative meaning, speech

\section{INTRODUCTION}

Semantics is the study of meaning in a wide sense that is communicated by language (Leech, 1981). Semantics is an important role regarding the case of 
communication. It is because the language has the means to speaker regarding conveying or communicating the meaning of his/her for the listener.

Every president has a special style in delivering a speech. They have different styles in persuading people. With a military background, President Susilo Bambang Yudhoyono (SBY) has a kind of discipline which is firmly disciplined and courageous. Starting the office through the general election, president SBY was directly chosen by the people in 2004, the sixth president Indonesia. According to Indonesian presidential interpreter, Muhammad Iqbal Sirie has an opinion on SBY's style of speech that SBY has his own style in delivering his speech. He has a lot of international levels meetings, complemented by the selection of words conveyed to his audience. President SBY tends to use official language,

(http:/ / m.liputan6.com/news/read/2362224/begini-gaya-bahasa-jokowi-dansby-According to -penerjemah-presidency, accessed on April 18 2017, 07:12 WIB)

SBY has made quite frequent speeches in his tenure, the words or sentences chosen by SBY had many meanings or messages. SBY who was once be the number one person in Indonesia has a background with very broad knowledge and has education in several countries abroad which makes him familiar with the society of different level, SBY has a very high repertoire language. The term repertoire is used for various languages that are known and used by someone in an association, work, and their affairs. It turns out that everyone masters and uses a lot of different kinds of mother tongue.

It is related to associative meaning because it is unstable of meaning and has variants of individual experience (Leech, 1974: 21). The associative meaning of expression has to do with the individual mental understanding of the speaker. They, in turn, can be broken up into five subtypes are connotative meaning, stylistic meaning, affective meaning, reflected meaning, and collocative meaning. In the other hand, it is the meaning of words that has a connection to the relationship of word with the condition beyond the language. For examples, the word "white" associates with the word of "holy," in the other way, while the word "black" associates with the word "darkness, sadness, and badness" because to understand the meaning, we need to know how words or sentences convey the meaning. The idea is that when we read texts; we try to know how words are put together to convey meaning so that they can be understood. It differs when we understand the meaning of speaking since sometimes it has the ambiguous meaning which makes the listener thinks more deeply to convey the meaning.

Based on the phenomenon above, the researcher is interested in analyzing SBY's speech to find out the types of meaning in order in SBY's speech. Semantics is one tool to analyze every sentence in ways to find out the meaning in the language used. The researcher chooses Geoffrey Leech1's Theory 
to understand the meaning. Generally, it is classified into seven types of meanings in which five of them are identified as associative meanings.

The researcher sees that every written text has associative meaning that links the meaning relations in the text contribute to its unity in order to help the readers understand well, we need the knowledge to minimize these misunderstandings so that the communication process can achieve a common goal. In addition, a word that is spoken by the speaker often means ambiguity which results in a person's speech not being smooth. The meaning of the word becomes blurred and the listener gets confused, it can even result in disharmony of an on-going conversation, so it becomes very urgent to know aspects of meaning formation for anyone, especially for language learners. Thus, this thesis is entitled Susilo Bambang Yudhoyono's Speech The Role Of The Military In Changing The World: Semantic Analysis

\section{METHODS}

The researcher applied the qualitative descriptive method where the researcher gradually made sense of social phenomenon by contrasting, comparing, replicating, cataloguing and classifying the object of the study. According to Miles, Huberman and Saldana (2014). Qualitative research was research which the data were collected and analyzed based on observations, interviews, documents, and artifacts.

Qualitative researchers usually tried to understand how things occur by going to the natural setting without implementing any intervention. The purpose of the qualitative method was to achieve an understanding of how people made sense of their lives. The data analysis consists of some current flew of activity: data collection, data condensation, data display, and conclusion drawing/verification. All these activities were involved in the whole process of this research.

\section{FINDINGS}

On the results of the associative meaning analysis above, it can be seen the percentage results from the elements that have been analyzed in associative meaning. Elements that exist in associative meaning include connotative meaning, affective meaning, social meaning, collocative meaning, and reflected meaning. After the researcher conducted the analysis, there were the types of associative meaning that appeared most based on percentages as follows:

There were 131 data used associative meaning. 58 data or $44,3 \%$ in affective meaning , 54 data or $41,2 \%$ in connotative meaning , 12 data or $9,2 \%$ social meaning, 4 data or $3,1 \%$ in reflected meaning, 3 data or 2,3\% collocative meaning. It can be seen in the part affective meaning that 
dominated the frequent type of associative meaning in SBY's speech. SBY's used a lot of affective meaning in his speech that meant he gave the feeling to hearer or reader is clear. In other word, it is the expression or communication of emotion or feeling of the speaker about something that is happened according to the situation.

Connotative meaning, in the connotative meaning it could be seen in the context, In example "corners of the world" meant that almost all places in the world had been colonized by terrorists, including major countries. It could be seen in the context when SBY was delivering his speech and explaining about the demand for terrorism acts.

Affective meaning, in the affective meaning is related to someone's feelings if they hear or read certain words. Feelings that appear can be positive or negative. The word honest, humble, and wise raises positive affective meanings, while corruption and collusion create negative affective meanings. When SBY was delivering his speech "I am fully aware" as stated in (S.115), that utterance conveyed by SBY when he argued about the international peace condition need to be maintained. So then, SBY made a statement "I am fully aware" as his personal expression that he cared for peace. Yet this utterance still affected by his personal feeling but the difference was here SBY emphasizes his utterance rather than the previous examples which only delivered without any specific emphasizing.

Reflected meaning, in the reflected meaning was the meaning that communicated through the association with another sense of the same expression of the word. 'Cold War' actually meant a war that was not involved physical fight. It was not indicated the damage such destroying building, burning a city, firing the gun. The term of 'Cold War' often classified as a war in enmity without hostilities or warfare. It such a hostile desire which deeply embedded in human thought. As in impact, the true physical warfare may be triggered.

Social meaning, in the social meaning was the meaning it refers to the usage of language in and by a society which has big proportions in determining the meaning that certain speaker has to use and wants to convey, in example "Peace be upon us all". Indeed this utterance categorized either into conceptual meaning or connotative meaning, but considering the context while SBY conveyed it, the utterance turned to have social value and circumstance. 
Collocative meaning, in the collocative meaning it refers to the associations a word acquires on account of the meanings of words which tend to occur in its environment, in example SBY said a phrase "Harmonious relation" in the middle of his speech. Conceptually in the context of relationship 'harmonious' was similar to friendly, amicable, cordial, amiable, agreeable, congenial, easy, peaceful, peaceable, conflict-free, cooperative, and good-natured. What should be underlined was not a similar word, but the phenomenon of how to match the word 'harmonious' could be met to the word 'relation' thus it was categorized as collocative meaning.

\section{CONCLUSION AND SUGGESTION}

In the result of the analyzed data, it was found that the SBY speech entitled "The Role of Military in a Changing World" used both types of associative meaning; Connotative meaning; social meaning; affective meaning; reflected meaning; and collocative meaning. It could be seen that affective meaning dominated the frequent type of associative meaning in SBY's speech with 58 utterances $(44,3 \%)$ from all total 131 utterances. This type was not much disparity within the number of connotative meaning used that only 3,1\% lower than affective meaning, about 54 utterances or in amount $41,2 \%$ rather than another two types which seemed to have a low priority to use.

In the use of social meaning, it was only discovered in amount 12 utterances $(9,2 \%)$. Then the least of all types of meaning used in SBY's speech was reflected and collocative meaning. The number of reflected and collocative meaning used only reached $3,1 \%$ and $2,3 \%$ or it was only $3-4$ utterances found from the whole of speech utterances. The reason why affective meaning dominantly appeared in SBY speech was that there was a personal influence from SBY's experiences and impressions which appropriate to the circumstance while he delivered his speech. That was his experiences and impression in military academy affected his speech in front of a thousand cadet military of the United States of America.

The researcher suggests conducting semantic research associated with the discourse analysis theory because by using that theory it was expected could help to interpret the meaning through the ideology contained in an utterance. In addition, it could be better also the researcher applied semiotic theory in order to help the researcher analyzed the depth meaning from video-based data. Last, it was suggested also that the researcher should make a comparison between the semantic meanings used by someone or thing with another one. For instance, was like the semantic meaning from Jokowi's speech and Prabowo's.

\section{REFERENCES}

Bloomfield, L. 1993. Language, London : University of Chicago Press. 
Djajasudarma \& Fatimah. T. 1999. Semantik 1: Pemahaman Ilmu Makna. Bandung: Penerbit PT Refika Aditama Bandung.

Finch \& Geoffrey. 1998. How to Study Linguistics. Hongkong: Machmillan.

Kreidler, C. W. 1998. Introducing English semantics. London: Routledge 11 New Fetter Lane..

Leech, G. 1974. Semantics. First published. London: Pelican Books.

Leech, G. 1981. Semantics: The Study of Meaning. Second Edition. London: Penguin Books.

Leech, G. 1991 "The state of the art in corpus linguistics", in Aijmer K. and Altenberg B. (eds.) English Corpus Linguistics: Studies in Honour of Jan Svartvik, 8-29. London: Longman.

Lyons, J. 1984. Introduction to Theoretical Linguistics. Melbourne: Cambridge University Press.

Lyons, J. 1995. Lingustic Semantics. Cambridge: Cambridge University Press.

Mulyana, Y. G. H. 1995. A Practical Guide for Public Speaking. Jakarta: Kesaint Blanc.

Miles, M. B \& Huberman, A. M . 1984. Qualitative Data Analysis. California: Sage Publications.

Miles, M. B , Huberman, A. M. \& Saldana, J. 2014. Qualitative Data Analysis A Method", Third Edition. California: Sage Publications.

Palmer, F. R. 1981. Semantics. Melbourne: Cambridge University Press.

Saeed, J. I. 1997. Semantics. Oxford: he Blackwell.

Steve, W. 1990. Research Methods and Analysis: Searching for Relationship. New York: Harper \& Row Publication.

Yule, G. 1985. The Study of Language: An Introduction. Melbourne: Cambridge University Press. 